\title{
Центральна та Східна Європа та Південний Кавказ у геополітичних концепціях президента Леха Качинського 2005-2010
}

\author{
Патрик Томашевськи ${ }^{1 \text { A }}$ \\ А Університет Миколи Коперніка в Торуні, вул. Баторего 39L, 87-100 Торунь, Польща
}

Received: January 25, 2020 | Revised: February 13, 2021 | Accepted: February 28, 2021

DOI: $10.33445 /$ sds.2021.11.1.3

\begin{abstract}
Анотація
Роздуми Леха Качинського на геополітичні теми стосувались переважно питань, пов'язаних з історичним розташуванням Польщі, особливо місцем Польщі та поляків на територіях Польщі до поділу. У його роздумах про зовнішню політику можна помітити посилання, які стосуються географічного положення Польщі в районі Балтійського моря та Чорноморської полоси, також зі стратегічної точки зору, далекосяжної, насамперед, стосовно енергетичних ресурсів Польщі. Беручи до уваги геополітику, географічне положення також розглядалося в контексті можливостей та загроз для ведення зовнішньоекономічної політики. За такого підходу можна побачити конкретні рішення, які пропагував президент Качинський, особливо стосовно міжнародної діяльності Польщі на пострадянському просторі. Особливо в контексті України (у довгостроковій перспективі також Республіки Молдова та Республіки Білорусь) та країн Балтії, з особливим акцентом на співпраці з Литовською Республікою, а також співпраці на Південному Кавказі $з$ Республікою Азербайджан, Республіка Вірменія і, перш за все, Грузія.

В статті автор представляє як геополітичну концепцію президента Леха Качинського, так $\mathrm{i}$ практичні елементи ії реалізації.
\end{abstract}

Ключові слова: Польська зовнішня політика, польська безпека, польська енергетична безпека.

\section{Постановка проблеми}

Вивчати питання пов'язані із зовнішньою політикою не можна без двох рівнів аналізу: практичного та теоретичного. Як зазначив Ришард Стемпловський, набагато простіше вивчати передбачувану функцію, але не можна ігнорувати практичної (Stemplowski, 2007: 12). У цій статті автор досліджує теоретичні концепції президента Леха Качинського в контексті геополітичних міркувань стосовно площі Центральної та Східної Європи та Південного Кавказу. Слід зазначити, що деякі президентські заходи та ініціативи виходили за рамки ідей, оскільки Лех Качинський мав шанс реалізувати конкретні концепції під час свого трагічно скороченого президентського терміну в 2005-

\section{0 роках.}

У своїх міркуваннях з геополітики Лешек Сикульський зазначив, що: “Геополітика завдяки предмету своїх інтересів знаходиться на стику між природничими та соціальними науками. Загалом кажучи, геополітика - це міждисциплінарна наука, яка вивчає вплив географії на політичні явища та процеси. Характерні дослідницькі підходи до геополітики включають процесуальний погляд, тобто розгляд досліджуваної реальності 3 точки зору процесів, використовуючи перспективу тривалості, тобто використання довгострокової призми у дослідженнях, часто секулярного - (цей термін розуміється як послідовність

\footnotetext{
${ }^{1}$ Corresponding author: кандидат соціальних наук, e-mail: patrykt@umk.pl, ORCID: 0000-0002-2333-9256
} 
фенотипових змін, що відбуваються 3 покоління в покоління, що має певний напрямок протягом більш тривалого періоду часу на даній території) і представлення політичної реальності в умовах постійної конкуренції за вплив, що відбувається між центрами влади" (Sykiulski, 2009: 180). 3 іншого боку, у геополітичному словнику той самий автор зазначив: “Галузь знань, що вивчає вплив географічних факторів на зовнішню політику держав та їх угруповань (міжнародні організації, політичні та військові блоки) та на формування міжнародного порядку і безпеки. Основними галузями досліджень $є$ суперництво влади та імперій протягом історії та спроба виявити закономірності в цій галузі" (Sykulski, 2014: 16-17). Визначення Л. Сикульського стосуються сприйняття геополітики як науки або складової інших наук. У політичних концепціях геополітика стає радше підходом, орієнтованим на ведення політики в часі та в конкретному просторі, беручи до уваги такі детермінанти, як влада, потенціал та ресурси держав (Łaszczuk, 2010: 71).

Застосовуючи вищезазначені визначення, слід зазначити, що міркування Леха Качинського на геополітичні теми стосувались насамперед питань, пов'язаних 3 історичним розташуванням Польщі, i особливо культуротворчим місцем Польщі та на території, що раніше належала Першій Речі Посполітої. 3 іншого боку, у роздумах про зовнішню політику можна побачити широку геополітичну перспективу, що стосується географічного розташування Польщі на Балтійсько-Чорноморській території. Крім того, зі стратегічної точки зору, далекосяжної щодо можливості отримання Польщею енергетичних ресурсів. У геополітичному плані географічне розташування також сприймається в контексті можливостей та загроз зовнішньоекономічній політиці, і в цьому підході можна побачити конкретні рішення, пропаговані президентом Лехом Качинським. Зокрема, з точки зору політики щодо України (у довгостроковій перспективі також Республіки Молдова та Республіки
Білорусь) та країн Балтії, 3 особливим акцентом на співпраці 3 Литовською Республікою. Більше того, співпраця на Південному Кавказі з Азербайджанською Республікою, Республікою Вірменія та Грузією (Dorota Litwin-Lewandowska, 2017: 185-205). 3 акцентом на співпрацю 3 останньою країною. Найважливішим у геополітичних концепціях Леха Качинського $\epsilon$ контекст Центральної та Східної Європи. Один із дослідників геополітичного розташування Польщі протягом століть та його наслідків писав: “Східна політика $\epsilon$ найважливішим напрямком польської політики. Саме в цій області відбувається "велика гра", кінцевий результат якої визначить нашу частину Європи [...]" (Żurawski vel Grajewski, 2010: 293-294).

Важливим для розуміння поведінки зовнішньої політики, і таким чином реалізації геополітичних припущень $€$ конституційні відносини між президентом Польщі та президентом Ради Міністрів (прем'єрміністром).

Під час президентства Леха Качинського багато суперечок було викликано відсутністю співпраці у зовнішній політиці між президентом та прем'єр-міністром. Тому на початку слід звернути увагу на стосунки у цій сфері між главою держави та президентом Ради Міністрів. В конституційному положенні ст. 146 параграфа 1 зазначено, що: “Рада міністрів проводить внутрішню та зовнішню політику Республіки Польща", ст. 9 параграфа 4, що: “вона здійснює загальне керівництво у сфері відносин 3 іншими державами та міжнародними організаціями". Тоді як ст. 133 описує повноваження Президента Республіки Польща у питаннях зовнішньої політики, в пункті 3 зазначено: “Президент Речі Посполітої у сфері зовнішньої політики взаємодіє з Президентом Ради Міністрів та відповідним міністром". Ришард Стемпловськи писав, що “Ця норма говорить про те, що президент зобов'язаний співпрацювати, але конституція чітко не визначає предметну сферу терміну “зовнішня політика", i іï розмовне розуміння дуже 
широке. Його конституційному розумінню певною мірою сприяють інші правові норми" (Stemplowski, 2007: 245). Важливим для розуміння ролі президента у проведенні зовнішньої політики є приведення фрагменту рішення Конституційного Трибуналу від 27 березня і 20 травня 2009 року. Трибунал у повному складі розглядав заяву Президента Ради Міністрів, що стосувалася суперечки з приводу повноважень, пов'язаних 3 визначенням центрального конституційного органу держави, який уповноважений представляти Республіку Польща в сесіях Ради Європи. Трибунал виніс рішення: «Співпраця Президента Республіки Польща, Президента Ради Міністрів та відповідного міністра згідно зі ст. 133 сек. 3 конституції означає взаємну відкритість для співпраці та ефективну готовність до ії здійснення. Конститутор включив до директиви про співпрацю всі форми діяльності Президента, Ради Міністрів та Президента Ради Міністрів, спрямовані “за межі" Республіки Польща. Співпраця, зазначена у ст. 133 сек. 3 Конституції стосується, насамперед, ситуації, коли Президент заявляє про свій намір взяти участь - через виконання завдань, зазначених у ст. 126 абзац 2 Конституції - на сесії Європейської Ради. Припускається, що Республіка Польща на сесії Європейської Ради представлена Президентом Ради Міністрів або призначеним міністром (членом Ради Міністрів); він представляє позицію Республіки Польща, встановлену Радою Міністрів. Угода між Президентом Ради Міністрів, відповідним міністром та Президентом Республіки Польща може дозволити інші форми представлення зазначеної тут позиції Республіки Польща, включаючи участь Президента в цій діяльності" (Конституційний Трибунал, рішення від 20 травня 2009 р).

Для того, щоб перейти до належних міркувань, необхідно згадати основні геополітичні концепції Польщі. Їх основою $€$ федералістська ідея. Слід підкреслити, ії антиросійський характер, що базується на прагненні відірвання від Росії держав, які $\epsilon$ своєрідним кордоном, що відокремлюють Польщу від східнього моцарства. Основним представником федералістської ідеї був Юзеф Пілсудський (Faryś 1982: 32). Вперше вона була представлена в 1882 році і чітко базувалася на Ягеллонських традиціях, тобто на створенні асоціації держав під егідою Польщі (Faryś 1993: 77). Вона не мала єдиної форми, і часто змінювалася. Її головним припущенням було створення системи незалежних національних держав: Литви, Латвії, Білорусі та України, а саме тих, нації яких були частиною багатоетнічної Речі Посполітої до 1772 року. Вони мали бути різними способами пов'язані з Польщею федеративні або пов'язані союзами. Ця концепція мала забезпечити мирне співіснування поруч один з одним. Міг би сформуватися блок держав, здатних спільно протистояти німецькому та російському імперіалізму. Саме останнє вважалося більш небезпечним, а Росія визнана найбільшим ворогом Польщі. Створення нових країн на території Російської імперії полягало у тому, щоб максимально ії послабити. Менша територія та демографічний потенціал, а також віддалення ії від найбільш економічно важливої частини, а саме України (Zaporowski, 2007: 179). Федералізм повинен був призвести до створення спільного потенціалу буферних держав, який би відібрали у Російської імперії (Moczulski, 1999: 562). Похідною федеральної концепції була так звана "Ягеллонська", яка відносилася до федеративної, але мала більш сильний тон і була пропагована середовищем молодих правих у 1926-1939 роках. Ця концепція була нездійсненною у 1930-х роках як через міжнародні умови, так і через відсутність економічного потенціалу Польщі.

Іншою, дуже важливою концепцією ведення зовнішньої політики був прометеїзм, що полягав у підтримці націй, що населяли Росію. Ослаблення Росії шляхом створення низки менших національних держав могло ефективно відокремити Польщу від Росії та спричинити розвиток співпраці 3 цими країнами (P. Libera, 2013: 31-56; Wyszczelski, 
2016: 25-26). Останньою великою концепцією, що стосується закордонних справ, є ідея Інтермаріум, також відома як концепція “Третьої Європи”. Це стосувалося країн Центральної Європи, що лежать між Балтійським, Адріатичним та Чорним морями. Вони перебували в схожій ситуації, що і Польща, тобто були під загрозою з боку двох агресивних моцарств. Швидко виключено (а скоріше за все вони самі вийшли, мова йде про часи Другої Польської Республіки) з цього союзу Чехословаччину та Литву, відносини яких з Республікою Польща були напружені. Спочатку ідея мала базуватися на домовленостях між зацікавленими сторонами, пізніше вона мала набути форми політичної та військової коаліції. Проблемою, яка перешкоджала фактичному здійсненню цієї ініціативи, були не стільки погані відносини Польщі з іншими країнами, зацікавленими в цій концепції, скільки погані стосунки між собою (наприклад, суперечка між Румунією та Угорщиною) (Kornat, 2007: 307).

Остання концепція посилалася на ідею Єжи Гедройця часів паризької "Культури" (період після 1947 р.) і говорила про “Доктрину Гедройця" або про “Доктрину України, Литви, Білорусі", простіше кажучи, що поляки повинні змиритися з нинішніми кордонами своєї країни і не висувати жодних ревізіоністських вимог проти України, Литви та Білорусі, а польська влада повинна підтримувати незалежність цих країн (Ceran 2010:120-134; Friszke 2007: 346-358).

\section{Виклад основного матеріалу}

Автор статті базує свої дослідження на когнітивному реалізмі. Питання дослідження, поставлене в статті, полягає в тому, наскільки Лех Качинський в своїх концепціях, що мають геополітичні особливості, відносився до концепції Міжмор'я, прометеїзму та федералізму?

Основна гіпотеза полягає в тому, що: геополітичні концепції Леха Качинського можна трактувати як “неофедералізм". Детальні гіпотези: Лех Качинський у своїх концепціях посилався на елементи політики концепції Міжмор'я, а в контексті країн Південного Кавказу, посилався також на прометеїзм. Чергова детальна гіпотеза стверджує, що Лех Качинський також посилався на пізніші свідчення Єжи Гедройця та Юліуша Мерошевського.

Методом використаним для дослідження $€$ насамперед аналіз змісту, з особливим акцентом на таких категоріях, як: інтереси країни, місце Польщі та поляків на БалтійськоЧорноморській території, відносини з Росією (як центром сили), Білорусією, країнами Балтії та Грузією, Молдовою, Азербайджаном та енергетична безпека регіону.

\footnotetext{
2 Роман Кузняр особливо негативно оцінює зовнішню політику PiS в 2005-2007 роках. (Kuźniar 2012: 295-296, 299, 334). Про зміни у
}

Без детального аналізу календаря політичної діяльності Леха Качинського у 2005-2010 роках слід зазначити, що зовнішня політика, а разом $з$ нею і деякі геополітичні концепції, створені Лехом Качинським, відповідали політиці, яку проводив коаліційний уряд “Право і справедливість", а після 2007 року ознаменувався суперечкою 3 урядом Дональда Туска та іншим підходом до зовнішньої політики. Особливо суттєвими були різниці відносно:

ролі Польщі в Європейському Союзі та способу проведення політики щодо Союзу;

зовнішньої політики Польщі щодо Російської Федерації;

зовнішньої політики щодо Федеративної Республіки Німеччина;

мультилатерального та білатерального співробітництва в регіоні Центральної та Східної Європи;

проведення заходів з метою енергетичної незалежності Польщі від поставок з Росії².

Висновки дослідження. Під час президентства Леха Качинського в геополітичному просторі на схід від кордонів Польщі особливо наголошувалося на

зовнішній політиці у 2007 році (Szpak, 2012, s. 14-15); (Zięba 2013: 8485, 131, 170, 193, 249-250); (Habowski 2011: 90-91); (Podgórzańska, 2010: 61-74). 
посиленні безпеки країн Балтії, партнерстві 3 Україною, а також демократизації Білорусі. У новорічному зверненні в 2005 році Президент сказав: “Що стосується нашого регіону, де Вишеградська група та відносини з країнами Балтії мають особливе значення. Сучасна Європа - це не лише Союз у теперішньому вигляді. Важливість наших відносин зі Сходом велика. $€$ всі шанси подальшого зміцнення наших зв'язків 3 Україною, нашого стратегічного партнерства. Я також хотів би висловити надію, що настане час значних змін у наших відносинах 3 Російською Федерацією. Ми хочемо, щоб свобода, демократія та повага до громадянських прав - включаючи права польської меншини - стали участю білоруського суспільства" (Новорічне послання президента Леха Качинського). Під час зустрічі з Головою Верховної Ради України Олександром Морозом у грудні 2006 р. Президент наголосив на підтримці європейських реформ в Україні (Президент Республіки Польща прийняв Голову Верховної Ради України). На саміті Північноатлантичного пакту в Ризі в листопаді 2006 року він наголосив на питаннях, пов'язаних з енергетичною політикою, які, однак, не були широко обговорені, та підтримці зусиль України та Грузії щодо вступу до НАТО. Підводячи підсумки саміту, він сказав: “Я хотів би, щоб процес розширення розпочався вже тут. Протягом місяців, проте, було відомо, що так не буде. Я думаю, що у нас $€$ шанс на 2008 рік, що стосується цієї географічної зони. Ми, звичайно, також зацікавлені і підтримуємо розширення НАТО на Балканах. На щастя, теза, яку я сформулював учора під час однієї з двосторонніх переговорів, якось відобразилась під час дискусії, що якщо мова йде про Грузію, то механізм працює наступним чином: членство в НАТО $\epsilon$ джерелом стабілізації і має допомогти вирішувати конфлікти, а не навпаки. Філософія, згідно з якою Грузія повинна спочатку вирішити всі конфлікти, зокрема 3 Абхазією та Осетією, і лише потім вступати до НАТО, є способом мислення, який у цьому випадку не підходить. На щастя, ми не самотні у своїй діяльності щодо України та Грузії, що чітко випливало 3 ходу зустрічі" (Важливий крок вперед). Президент Качинський хотів зміцнити позиції згаданої України та Грузії в системі безпеки, одночасно розуміючи, що питання Абхазії та Південної Осетії $\epsilon$ надто складним, щоб Тбілісі самостійно швидко з ним впоралося. 14 грудня 2006 р. Президент Республіки Польща Лех Качинський відправився до Брюсселя на засідання Європейської Ради, під час якого підтримав європейські прагнення Балкан та закликав не забувати про Україну та Грузію (участь Президента у засіданні Європейської Ради). Під час свого візиту до Грузії 22 листопада 2007 року Лех Качинський говорив про необхідність скласти дорожню карту для вступу цієї країни до НАТО, а в майбутньому також до $€ С$. Він зазначив, що підтримує прозахідні прагнення уряду в Києві (візит Президента Польської Республіки до Грузії).

У грудні 2007 р. Президент Качинський та Віктор Ющенко підписали документ “Спільні виклики - нові виміри стратегічного партнерства". У ньому писалося про молодіжну співпрацю та створення спільного фонду, а Президент Качинський наголосив, що підтримує зусилля України щодо вступу до ЄC (президенти Качиньський та Ющенко підписали декларацію про співпрацю). Під час зустрічі з послами ЄС, а також України, Туреччини та Хорватії президент Качинський сказав: “Польща також $\epsilon$ стратегічним партнером деяких країн, які сьогодні не входять до ЄС чи НАТО. Ми говоримо зокрема про Україну, але ми наближаємось до стратегічного партнерства з Грузією, дуже хороші відносини з Азербайджаном. Іншими словами, для Польщі Союз залишається головною точкою відліку, але Польща також має свою власну концепцію розвитку Європейського Союзу. І про ці питання, як i щороку, я буду дуже радий поговорити 3 вами за хвилину" (Зустріч Президента Республіки Польща з Послами).

Ключовими подіями в ситуації, пов'язаній з Південним Кавказом, були події серпня 2008 року, коли грузинські війська 
намагались захопити і завоювати Південну Осетію, що було зумовлено непропорційно сильною участю Російської Федерації в конфлікті, що призвело до стратегічної поразки Грузії після 5 днів конфлікту. мирних переговорах були задіяно багато країн, на думку західноєвропейських коментаторів, найважливішим було посередництво президента Франції Ніколя Саркозі, тоді як у Центральній та Східній Європі визнали, що особою, яка однозначно підтримала Грузію в конфлікті був президент Лех Качинський. Повертаючись до цих подій, варто нагадати, що під час прес-конференції в Москві президент Ніколя Саркозі заявив, що Росія має право захищати своїх громадян за кордоном. Того ж дня - 12 серпня - на мітингу в Тбілісі лідери Польщі, Литви, Латвії, Естонії та України надали Грузії повну підтримку в конфлікті з Росією (Brążkiewicz 2010: 92-102). Потім президент Качинський сказав: “Коли я ініціював цей візит, дехто думав, що президенти будуть боятися. Ніхто не боявся. Усі вони приїхали, бо Центральна Європа має мужніх лідерів. І я хотів би сказати це не тільки вам, я також хотів би сказати це тим, 3 нашого спільного Європейського Союзу, що Центральна Європа, Грузія, що весь наш регіон буде рахуватися, що ми є суб'єктом. । ми також добре знаємо, що сьогодні Грузія, завтра Україна, післязавтра країни Балтії, а потім, можливо, час для моєї країни, для Польщі!" (Часи панування Росії минули назавжди).

Незважаючи на складне партнерство 3 Литовською Республікою, спричинене різною інтерпретацією історичних подій, а також досить прохолодною політикою влади у Вільнюсі щодо Варшави, Лех Качинський намагався зміцнити співпрацю між країнами, особливо в контексті енергетичних проектів, а також спільної політики безпеки в регіоні. На початку листопада 2007 року, під час нагородження Єжи Гедройц, президент Качинський, сказав Богдану Осадчуку про стосунки з Литвою та іншими сусідами: “Ми також, безперечно, $є$ речником української справи в Європі. Ми є, і я сподіваюся, що залишимося. Те саме стосується країн на сході (Грузії та Азербайджану), про що я щойно сказав. На схід від Польщі, хоча i північний, знаходиться також Литовська Республіка та інші дві країни Балтії. Я можу сказати, що за останні два роки, хоча траплялися випадки, коли виникали труднощі, нам вдалося встановити дуже тісні стосунки зокрема з Литвою та президентом Адамкусом" (Реалізовано заповіт Гедройця).

У 2007 році під час зустрічі Качинського та Адамкуса вони обмінялись думками щодо поточної програми роботи Європейського Союзу та спільних проектів Польщі та Литви на Європейському форумі. Також були обговорені питання енергетичної безпеки обох країн та реалізації проектів у цій галузі (зустріч президентів Польщі та Литви).

Особливо важливими були питання, пов'язані з постачанням енергії до Польщі та інших країн регіону. Перш за все, мова йшла про завершення будівництва нафтопроводу Одеса-Броди-Плоцьк-Гданськ, і зрештою 3 нафтових родовищ Азербайджану, нафтопроводом чи залізницею до грузинських портів Чорного моря, потім морем до Одеси, а потім нафтопроводом до Гданьська (Chmielecki, Cenckiewicz 2016: 285; Rudnytska 2015: 104). Аналітики Бюро національної безпеки у 2006 році позитивно висловились про концепцію.

Діяльність Леха Качинського у 2007 р. Були заплановані великі економічні та геостратегічні заходи, метою яких був імпорт нафти 3 південно-східного напрямку, 3 Казахстану, Азербайджану через Грузію, Україну до Польщі та далі через Гданськ і, можливо, по трубопроводу, що веде до Німеччини (Візит президента України). Лех Качинський згадував про газову співпрацю, перебуваючи в Астані під час зустрічі в березні 2007 року 3 президентом Нурсултаном Назарбаєвим (Президент Качинський буде говорити). Нарешті, 11 травня 2007 року в Кракові відбувся енергетичний саміт, у якому взяли участь: Президент Азербайджанської Республіки Ільхам Алієв, Президент Грузії Михайл Саакашвілі, Президент Литовської Республіки Валдас Адамкус, Президент України Віктор 
Ющенко та Ляззат Кійнов, спеціальний посланник Президента Республіки Казахстан, державний секретар Міністерства енергетики та мінеральних ресурсів (Президентський енергетичний саміт у Кракові). Після зустрічі в Кракові відбулися інші - у Вільнюсі, Києві та Баку. Під час енергетичного саміту в столиці Азербайджану 14 листопада 2008 року Лех Качинський сказав: “Я не приховую, що крім нафтових питань, мене, як представника польської держави, також інтересують поставки газу, і що величезні ресурси, які має в розпорядженні Азербайджан, також повинні бути використані з нашої точки зору, звичайно, я говорю про польську, але також і про євросоюзівську у різних напрямках, включаючи Північно-Західному" (Участь Президента Республіки Польща в Енергетичному Саміті в Баку).

Діяльність міжнародного консорціуму “Сарматія". Зміни в Україні, а також добудова другої гілки нафтопроводу Баку-ТбілісіДжейхан, а також відсутність спільного бачення енергетичної політики в Польщі через різні бачення між президентським центром та урядом, не призвели до остаточного запропонованого рішення. В контексті діяльності в енергетичному секторі важливо було залучити зусилля щодо придбання литовського нафтопереробного заводу в Мажейкяї концерном Orlen. В геополітичному контексті ця інвестиція мала посилити енергетичні зв'язки між Польщею та країнами Балтії. Однак польська енергетична політика зустріла реакцію Російської Федерації, в 2006 році російська компанія "Транснефть" припинила поставки сирої нафти в ORLEN Lietuva по трубопроводу "Дружба Північ", пояснивши це аварією трубопроводу. Трубопровід не працює до сьогодні, тому сира нафта доставляється в ORLEN Lietuva залізничним транспортом, що збільшує витратність. Дії Леха Качинського мали форму компактної концепції, наслідком якої було посилення енергетичних ресурсів Польщі та країн-учасниць проекту, водночас зменшуючи роль Росії.
У концепціях Леха Качинського ми не знайдемо багато місця, присвяченого політиці щодо Республіки Білорусь, особливо в ширшому контексті стратегічної діяльності щодо цієї країни.

Окрім міркувань у цій статті, $\epsilon$ також питання, пов'язані зі сприйняттям ролі Російської Федерації в геополітичному контексті Президентом Качинським. Безсумнівно, його сприйняття Росії грунтувалося на припущенні, що вона прагне відновлення впливу пострадянського простору, і особливо зацікавлена в дестабілізації ситуації на Південному Кавказі, Молдові, а також в Україні та країнах Балтії.

щодо національної спільноти та історичних умов, він не забув про зв'язки 3 поляками, сказавши: “В цей останній день року ми подумки обіймаємо поляків розсіяних по всьому світу. Нащадків вигнанців у Сибіру та Казахстані, поляків Литви, Білорусі, України та Заолжя. Пишаються своїм польським корінням, польсько-американською громадою та тими, хто останніми роками з метою роботи виїхав до Великобританії, Ірландії та інших європейських країн" (Новорічне привітання Президента 2007 року). Поляки за кордоном мали не лише підтримувати культурні зв'язки зі своєю батьківщиною, а й стати ії "послами" в цих країнах. У контексті історичної політики Качинський сказав: “Польща та Литва протягом багатьох років були пов'язані особливими зв'язками дружби та партнерства. Також нас об'єднує багатовікова спільна історія та традиції, а також досвід поневолення комуністичною системою. Цей досвід змушує нас добре розуміти цінність життя в суверенній, незалежній та вільній країні. Сьогодні ми разом підтримуємо інші країни нашого регіону на їх шляху до свободи. Ми прагнемо забезпечити повну реалізацію Принципу солідарності на форумі Європейського Союзу та НАТО, щоб забезпечити умови безпеки та розвитку для всіх держав-членів та країн-кандидатів" (Візит президентської пари у Вільнюсі). 


\section{Висновки}

Сприйняття питань, пов'язаних із геостратегічних умов, пов'язаних із зовнішньою політикою та безпекою, розташуванням Польщі. Президент Лех представлене Лехом Качинським, вийшло за Качинський був особливо активним у рамки традиційного ведення зовнішньої дипломатичній секції з Литвою, Україною та політики і було частиною геополітичних Грузією. Якщо припустити, що одним із концепцій. Важко не погодитись із заходів активності $\epsilon$ кількість візитів до твердженням Павла Коваля про те, що Лех окремих країн, то особливо багато разів він Качинський відновив геополітичний підхід у відвідував Литву (16 разів) та Грузію (7 разів). зовнішній політиці (Kowal 2010: 39-30). Це Україну більше відвідував Броніслав слід розуміти як розгляд не лише поточних Коморовський - 11, президент Качинський 9 зовнішньополітичних питань, а й тільки.

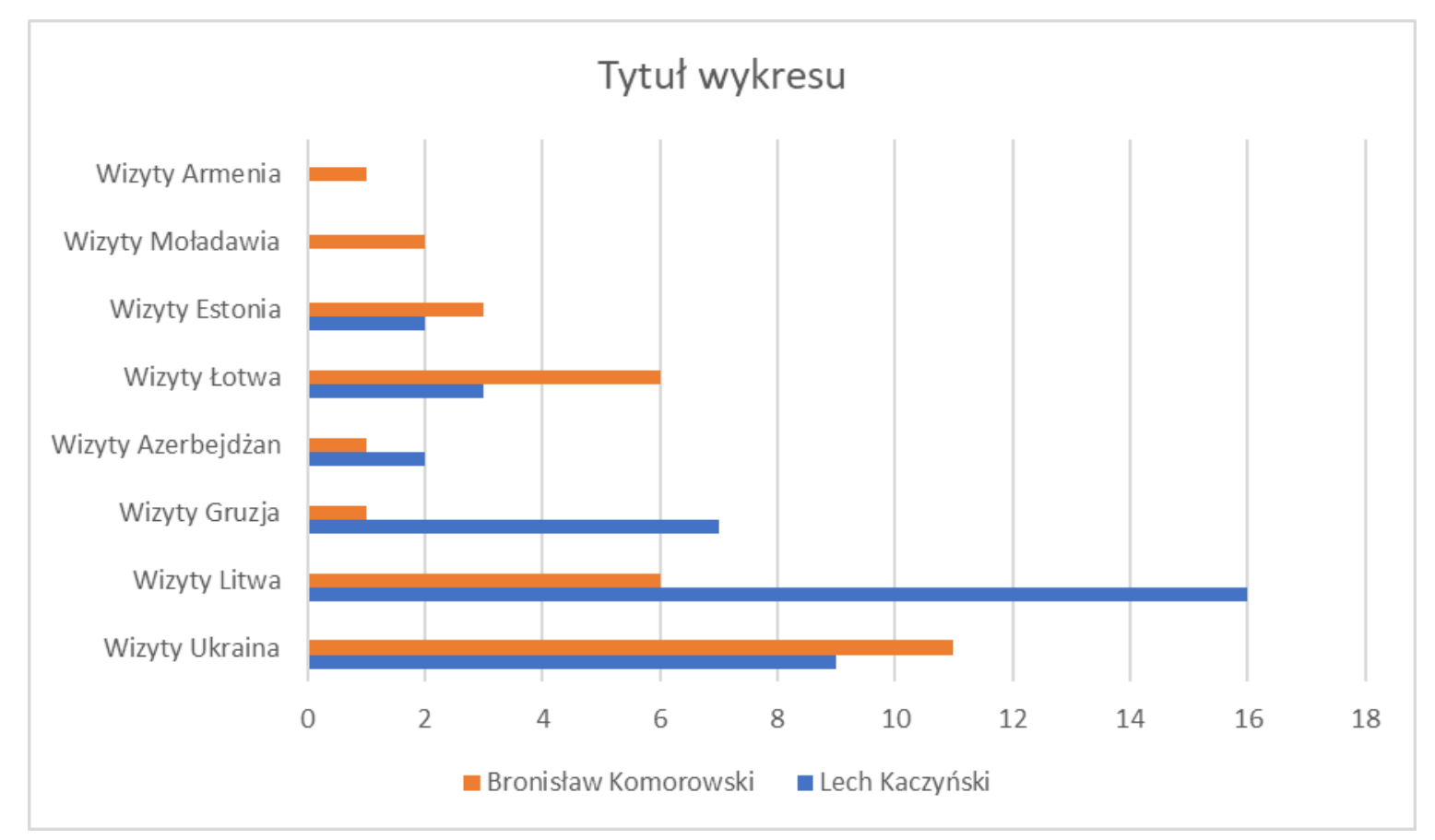

Малюнок 1 - Список візитів президентів Леха Качинського та Броніслава Коморовського Компіляція на основі інформації з канцелярії президента

Концепції та дії президента Леха Качинського носили ознаки “неофедералізму", насамперед у контексті політики щодо України. Можна зробити висновок, що вони узгоджувались із деякими припущеннями “Доктрини України, Литви, Білорусі", але не в однаковій мірі для всіх країн. Це було головним чином через відсутність активної політики, особливо бачення взаємних відносин 3 Білоруссю. Тому існувала певна асиметрія в контексті України, Литви та Білорусі. Яцек Бартосік посилаючись до самих початків польської політики (у 1991 році) стосовно Білорусі зазначав, що незалежно від ситуації в цій країні потрібно було усвідомити, що належне функціонування Польщі залежить від забезпечення "Смоленських воріт", а це від відносин з Білоруссю (Bartosiak 2018: 178). Найважливішим партнером у концепціях Леха Качинського була Україна, це було пов'язано як 3 її геостратегічним розташуванням у контексті поставок сирої нафти, так і через перебування в буферній зоні щодо геополітичних прагнень Російської Федерації. "Нефедералізм" був розширений, включивши неопрометейські елементи (Елементи такого підходу до політики можна побачити також у “Східному партнерстві", яке пропагують Польща та 
Швеція (це, насамперед, була ініціатива міністрів закордонних справ Швеції та Польщі: Карла Більдта та Радослава Сікорського), яке на основі soft power мала впливати на демократичні та вестернізовані країни, такі як: Грузія, Вірменія, Азербайджан, Молдова, Білорусь, Україна.), особливо з 2008 року в контексті відносин із країнами Південного Кавказу не лише в концепціях, а й у політичній практиці Леха Качинського. В геополітичній думці президента Качинського не було видимих прямих посилань на ідею Міжмор'я. Якщо Міжмор'я було предметом інтересу, віно, скоріше, як зазначав Лешек Сикульський, було у сентиментальній формі як Список використаних джерел

Bartosiak, J. (2018), Rzeczpospolita między lądem a morzem. O wojnie i pokoju, Zona Zero. Warszawa.

Brążkiewicz D., (2010), Wojna rosyjskogruzińska, Kwartalnik Bellona, $\mathrm{nr} 1$.

Ceran, T., (2010), Historia i polityka - światy przeciwstawne? Na marginesie myśli Juliusza Mieroszewskiego, Historia i Polityka, nr 4.

Chmielecki A, Cenckiewicz, S., (2016), Prezydent Lech Kaczyński 2005-2010, Wydawnictwo Fronda, Warszawa 2016.

Faryś J., (1982), Koncepcje polskiej polityki zagranicznej 1918-1939, Książa i Wiedza, Warszawa.

Faryś J., (1993), Koncepcja, czy koncepcje polskiej polityki zagranicznej w latach 19211939, Uniwersytet Szczeciński, Szczecin.

Friszke A., (2007), Między Niemcami, Rosją a ULB. Program geopolityczny paryskiej "Kultury", [w:] Przystosowanie i opór. Studia z dziejów PRL, A. Friszke (red.), Wydawnictwo Więzi, Warszawa.

Habowski M., (2011), Polityka wschodnia rządu Donalda Tuska, Wschodoznastwo, nr 5.

Kornat M., (2007), Polityka równowagi 19341939. Polska między Wschodem a Zachodem, Wydawnictwo Arcana, Kraków.

Kowal P., (2010), Wielki powrót geopolityki i wschodnia idea Lecha Kaczyńskiego, [w:] J Polska w grze międzynarodowej. Geopolityka i sprawy wewnętrzne, Kloczkowski (red.), Ośrodek Myśli Politycznej, Kraków. частина Ягеллонської ідеї, яка все-таки лежала в основі неофедеральної політики (Sykulski 2018:156). Тож основна гіпотеза підтвердилася, тоді як докладні гіпотези про те, що Лех Качинський посилався у своїх концепціях на елементи політики ідей Міжмор'я, а в контексті країн Південного Кавказу - на концепцію прометеїзму, незважаючи на певну асиметрію деяких постулатів “Доктрини ULB”. Слід додати, що президентство Леха Качинського - це також спроба узгодити довгострокове бачення співпраці в регіоні зі складними елементами історичної політики, особливо проблем оцінки минулих подій політиками з Варшави, Києва та Вільнюса.

Kuźniar R., (2012), Polityka zagraniczna III Rzeczypospolitej, Wydawnictwo Naukowe Scholar, Warszawa.

Łaszczuk A. (2010), Analiza geopolityczna potęgi państwa, [w:] Geopolityka. Elementy teorii, wybrane metody i badania, Lach, J. Wendt (red.), Instytut Geopolityki, Częstochowa.

Libera P., (2013), Zarys historii Ruchu Prometejskiego, [w:] II Rzeczpospolita wobec Ruchu Prometejskiego, P. Libera (red.), t. 4, Centralne Archiwum Wojskowe im. mjr. Bolesława Waligóry, Warszawa.

Litwin-Lewandowska D., (2017), Gruziński epizod w polskiej polityce zagranicznej w okresie prezydentury Lecha Kaczyńskiego (2005-2010), “Annales Uniwersitatis Mariae Curiae-Skłodowska Lublin - Polonia". Sectio M, vol. II, DOI: 10.17951/m.2017.2.185

Moczulski L., (1999), Geopolityka. Potęga w czasie i przestrzeni, Wydawnictwo Bellona, Warszawa.

Podgórzańska R., (2010), Polityka zagraniczna w kampaniach wyborczych Lecha Kaczyńskiego i Donalda Tuska w 2005 roku - prognoza na 2010 rok, Kultura i Edukacja, nr 3.

Rudnytska U., (2015), The prospects for Baltic Black Sea cooperation in the context of current Russian-Ukrainian relations, Torun International Studies, No. $1 . \quad$ DOI: http://dx.doi.org/10.12775/TIS.2015.009.

Stemplowski R., (2007), Wprowadzenie do analizy polityki zagranicznej RP, Polski 
Instytut Spraw Międzynarodowych, Warszawa.

Sykulski L., (2009), Geopolityka akademicka między nauką a paradygmatem. Spór wokół semiotyki geopolitycznej, [w:] Między historią a geopolityką, R. Domke (red.), Instytut Geopolityki, Częstochowa.

Sykulski L., (2014), Geopolityka, skrypt dla początkujących, Wydawnictwo Naukowe Grategia, Częstochowa.

Sykulski L., (2018), Geopolityka a bezpieczeństwo Polski, Zona Zero, Warszawa.

Szpak K., (2012), Założenia programowe polityki zagranicznej koalicji rządowej PO-PSL w latach 2007-2011, [w:] Główne kierunki polityki zagranicznej rządu Donalda Tuska w latach 2007-2011, P. Musiałek (red.), Klub Jagielloński, Wydawnictwo eSPe, Kraków.

Wołos M., (2019), Koncepcja federacyjna Józefa Piłsudskiego nigdy nie umarła do końca, URL : https://dzieje.pl/aktualnosci/prof-m-woloskoncepcja-federacyjna-jozefa-pilsudskiegonigdy-nie-umarla-do-konca.

Wyszczeleki L., (2016), Rozumowanie Rosji. Prometeizm - idea i realizacja, Wydawnictwo Bellona, Warszawa.

Zaporowski Z., (2007), Federalizm Józefa Piłsudskiego 1918-1922, [w:] W. Paruch, K. Trembicka (red.), Świat wokół Rzeczpospolitej: problematyka zagraniczna w polskiej myśli politycznej w pierwszej połowie XX wieku, Wydawnictwo UMCS, Lublin.

Zięba R., (2013), Polityka zagraniczna Polski w strefie euroatlantyckiej, Wydawnictwo UW, Warszawa.

Żurawski vel Grajewski P., (2010), Geopolitykasiła-wola. Rzeczpospolitej zmagania z losem, Wydawnictwo Arcana, Kraków.

Важливий крок вперед, (2018), URL : https://www.prezydent.pl/archiwum-lechakaczynskiego/aktualnosci/rok2006/art,150,886, wazny-krok-naprzod.html.

Виконано заповіт Гедройця, URL : https://www.prezydent.pl/archiwum-lechakaczynskiego/aktualnosci/rok2007/art,149,963, realizowany-jesttestament-giedroycia.html

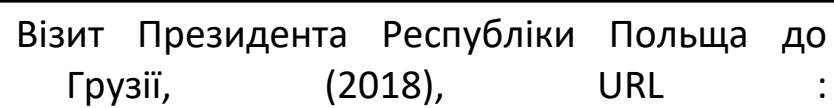
https://www.prezydent.pl/archiwum-lechakaczynskiego/aktualnosci/rok-

2007/art,149,901, wizyta-prezydenta-rp-wgruzji.html

Візит Президента України, (2017), URL : https://www.prezydent.pl/archiwum-lechakaczynskiego/aktualnosci/rok2007/art,149,83,wizyta-prezydentaukrainy.html.

Візит президентської пари у Вільнюс, (2017), URL : https://www.prezydent.pl/archiwumlecha-kaczynskiego/aktualnosci/rok2007/art,149,132, wizyta-paryprezydenckiej-w-wilnie.html.

Зустріч Президента Республіки Польща 3 Послами, (2018), URL https://www.prezydent.pl/archiwum-lechakaczynskiego/aktualnosci/rok2007/art,149,863,spotkanie-prezydenta-rpz-ambasadorami.html.

Зустріч президентів Польщі та Литви, (2018), URL : https://www.prezydent.pl/archiwumlecha-kaczynskiego/aktualnosci/rok2007/art,149,234,spotkanie-prezydentowpolski-i-litwy.html.

Новорічне звернення Президента Леха Качинського, (2017), URL : https://www.prezydent.pl/archiwum-lechakaczynskiego/aktualnosci/rok2005/art,151,415,oredzie-noworoczneprezydenta-rp-lecha-kaczynskiego.html.

Новорічне звернення Президента, (2017), URL: https://www.prezydent.pl/archiwumlecha-kaczynskiego/aktualnosci/rok2007/art,149,804,oredzie-noworoczneprezydenta-rp.html.

Президент Качинський розмовлятиме у Казахстані про постачання нафти, (2007), URL : https://www.bankier.pl/wiadomosc/ Prezydent-Kaczynski-bedzie-rozmawial-wKazachstanie-o-dostawach-ropy1565036.html.

Президенти Качинський та Ющенко підписали декларацію про співпрацю, (2017), URL : https://www.wprost.pl/ swiat/119177/Prezydenci-Kaczynski-i- 
Juszczenko-podpisali-deklaracje-owspolpracy.html.

Президентський енергетичний саміт Кракові, (2018), URL https://www.prezydent.pl/archiwalneaktualnosci/rok-2007/art,443, prezydenckiszczyt-energetyczny-w-krakowie.html.

Розпорядження Конституційного трибуналу від 20 травня 2009 р., Sygn. akt Kpt 2/08, URL : http://www.trybunal.gov.pl/ rozprawy/2009/kpt_02_08.htm.

Участь Президента Республіки Польща в Енергетичному Саміті в Баку, URL : https://www.prezydent.pl/archiwum-lechakaczynskiego/aktualnosci/rok- 2008/art,148,953,udzial-prezydenta-rp-wszczycie-energetycznym-w-baku.html.

Участь Президента у засіданні Європейської ради, (2017), URL https://www.prezydent.pl/archiwum-lechakaczynskiego/aktualnosci/rok2006/art,150,819,udzial-prezydenta-rp-wposiedzeniu-rady-europejskiej.html.

Часи панування Росії минули назавжди. 11. річниця виступу Леха Качинського в Тбілісі. (2019). URL : https://www.tvp.info/ 43899511/czasy-dominacji-rosji-sieskonczyly-na-zawsze-11-rocznicaprzemowienia-lecha-kaczynskiego-w-tbilisi.

\title{
Центральная, Восточная Европа и Южный Кавказ в геополитических концепциях президента Леха Качиньского 2005-2010
}

\author{
Патрик Томашевськи ${ }^{1 \text { A }}$ \\ ${ }^{1}$ Corresponding author: кандидат социальных наук, e-mail: patrykt@umk.pl, ORCID: 0000-0002-2333-9256 \\ А Университет Николая Коперника в Торуни, ул. Баторего 39L, 87-100 Торунь, Польша
}

\begin{abstract}
Аннотация
Размышления Леха Качиньского на геополитические темы касались преимущественно вопросов, связанных с историческим расположением Польши, особенно местом Польши и поляков на территориях Польши к делению. В его размышлениях о внешней политике можно заметить ссылки, касающиеся географического положения Польши в районе Балтийского моря и Черноморской полосы, также со стратегической точки зрения, долгосрочной, прежде всего, в отношении энергетических ресурсов Польши. Принимая во внимание геополитику, географическое положение также рассматривался в контексте возможностей и угроз для ведения внешнеэкономической политики. При таком подходе можно увидеть конкретные решения, которые пропагандировал президент Качиньский, особенно в отношении международной деятельности Польше на постсоветском пространстве. Особенно в контексте Украины (в долгосрочной перспективе также Республики Молдова и Республики Беларусь) и стран Балтии, с особым акцентом на сотрудничестве с Литовской Республикой, а также сотрудничества на Южном Кавказе с Республикой Азербайджан, Республика Армения и, прежде всего, Грузия.

В статье автор представляет как геополитическую концепцию президента Леха Качиньского, так и практические элементы ее реализации.
\end{abstract}

Ключевые слова: Польская внешняя политика, польская безопасность, польский энергетическая безопасность.

\section{Central and Eastern Europe and the Southern Caucasus in the geopolitical concepts of President Lech Kaczyński 2005-2010}

Patrick Tomaszewski ${ }^{1}$ A 
${ }^{1}$ Corresponding author: Candidate of Social Sciences, e-mail: patrykt@umk.pl, ORCID: 0000-0002-2333-9256

A Nicolaus Copernicus University in Toruń, vul. Batorego 39L, 87-100 Torun, Poland

\begin{abstract}
Lech Kaczyński's reflections on geopolitical issues were mainly related to the issues connected with the historical location of Poland, and especially the place of Poland and Poles in the prepartition Poland. On the other hand, in his reflections on foreign policy one can notice observations relating to Poland's geographical location in the area of the Baltic-Black Sea Belt, also from a strategic perspective, far-reaching in relation primarily to Poland's energy resources. Considering the geopolitics, the geographical location was also seen in the context of opportunities and threats for conducting foreign and economic policy, and in such an approach one can notice the specific solutions promoted by President Kaczyński, especially as regards Poland's international activity in the prospect of activity in the post-Soviet area. Especially in the context of Ukraine (in a longer perspective also the Republic of Moldova and the Republic of Belarus) and the Baltic States, with particular emphasis on cooperation with the Republic of Lithuania, as well as cooperation in the Southern Caucasus with the Republic of Azerbaijan, the Republic of Armenia and, above all, Georgia.

In the article the author presents both the geopolitical concept of President Lech Kaczyński and the practical elements of its implementation.
\end{abstract}

Keywords: Polish foreign policy, Polish security, Polish energy security.

\title{
References
}

An important step forward, (2018), URL: https://www.prezydent.pl/archiwum-lechakaczynskiego/aktualnosci/rok-

2006/art,150,886, wazny-krok-naprzod.html.

Bartosiak, J. (2018), Rzeczpospolita między lądem a morzem. O wojnie i pokoju, Zona Zero. Warszawa.

Brążkiewicz D., (2010), Wojna rosyjskogruzińska, Kwartalnik Bellona, nr 1.

Ceran, T., (2010), Historia i polityka - światy przeciwstawne? Na marginesie myśli Juliusza Mieroszewskiego, Historia i Polityka, nr 4.

Chmielecki A, Cenckiewicz, S., (2016), Prezydent Lech Kaczyński 2005-2010, Wydawnictwo Fronda, Warszawa 2016.

Faryś J., (1982), Koncepcje polskiej polityki zagranicznej 1918-1939, Książa i Wiedza, Warszawa.

Faryś J., (1993), Koncepcja, czy koncepcje polskiej polityki zagranicznej w latach 19211939, Uniwersytet Szczeciński, Szczecin.

Friszke A., (2007), Między Niemcami, Rosją a ULB. Program geopolityczny paryskiej "Kultury", [w:] Przystosowanie i opór. Studia z dziejów PRL, A. Friszke (red.), Wydawnictwo Więzi, Warszawa.

Gedroyc's will fulfilled, URL: https://www.prezydent.pl/archiwum-lecha- kaczynskiego/aktualnosci/rok2007/art,149,963, realizowany-jesttestament-giedroycia.html

Habowski M., (2011), Polityka wschodnia rządu Donalda Tuska, Wschodoznastwo, nr 5.

Kornat M., (2007), Polityka równowagi 19341939. Polska między Wschodem a Zachodem, Wydawnictwo Arcana, Kraków.

Kowal P., (2010), Wielki powrót geopolityki i wschodnia idea Lecha Kaczyńskiego, [w:] J Polska w grze międzynarodowej. Geopolityka i sprawy wewnętrzne, Kloczkowski (red.), Ośrodek Myśli Politycznej, Kraków.

Kuźniar R., (2012), Polityka zagraniczna III Rzeczypospolitej, Wydawnictwo Naukowe Scholar, Warszawa.

Łaszczuk A. (2010), Analiza geopolityczna potęgi państwa, [w:] Geopolityka. Elementy teorii, wybrane metody i badania, Lach, J. Wendt (red.), Instytut Geopolityki, Częstochowa.

Libera P., (2013), Zarys historii Ruchu Prometejskiego, [w:] II Rzeczpospolita wobec Ruchu Prometejskiego, P. Libera (red.), t. 4, Centralne Archiwum Wojskowe im. mjr. Bolesława Waligóry, Warszawa.

Litwin-Lewandowska D., (2017), Gruziński epizod w polskiej polityce zagranicznej w okresie prezydentury Lecha Kaczyńskiego 
(2005-2010), “Annales Uniwersitatis Mariae Curiae-Skłodowska Lublin - Polonia". Sectio M, vol. II, DOI: 10.17951/m.2017.2.185

Meeting of the President of the Republic of Poland with the Ambassadors, (2018), URL: https://www.prezydent.pl/archiwum-lechakaczynskiego/aktualnosci/rok-

2007/art,149,863,spotkanie-prezydenta-rpz-ambasadorami.html .

Meeting of the Presidents of Poland and Lithuania, (2018), URL: https://www.prezydent.pl/archiwum-lechakaczynskiego/aktualnosci/rok2007/art,149,234,spotkanie-prezydentowpolski-i-litwy.html.

Moczulski L., (1999), Geopolityka. Potęga w czasie i przestrzeni, Wydawnictwo Bellona, Warszawa.

New Year's address by President Lech Kaczynski, (2017), URL: https://www.prezydent.pl/archiwum-lechakaczynskiego/aktualnosci/rok2005/art,151,415,oredzie-noworoczneprezydenta-rp-lecha-kaczynskiego. html.

New Year's address of the President, (2017), URL: https://www.prezydent.pl/archiwumlecha-kaczynskiego/aktualnosci/rok2007/art,149,804,oredzie-noworoczneprezydenta-rp.html.

Order of the Constitutional Tribunal of 20 May 2009, Sygn. act Kpt 2/08, URL: http://www.trybunal.gov.pl/ rozprawy / 2009 / kpt_02_08.htm.

Participation of the President in the meeting of the European Council, (2017), URL: https://www.prezydent.pl/archiwum-lechakaczynskiego/aktualnosci/rok2006/art,150,819,udzial-prezydenta-rp-wposiedzeniu-rady-europejskiej.html.

Participation of the President of the Republic of Poland in the Energy Summit in Baku, URL: https://www.prezydent.pl/archiwum-lechakaczynskiego/aktualnosci/rok-

2008/art,148,953,udzial-prezydenta-rp-wszczycie-energetycznym- w-baku.html.

Podgórzańska R., (2010), Polityka zagraniczna w kampaniach wyborczych Lecha Kaczyńskiego i Donalda Tuska w 2005 roku - prognoza na
2010 rok, Kultura i Edukacja, nr 3.

President Kaczynski will discuss oil supplies in Kazakhstan, (2007), URL: https://www.bankier.pl/wiadomosc/ Prezydent-Kaczynski-bedzie-rozmawial-wKazachstanie-o-dostawach-ropy1565036.html.

Presidential Energy Summit in Krakow, (2018), URL: https://www.prezydent.pl/archiwalneaktualnosci/rok-2007/art,443, prezydenckiszczyt-energetyczny-w-krakowie.html.

Presidents Kaczynski and Yushchenko signed a declaration of cooperation, (2017), URL: https://www.wprost.pl/ swiat / 119177 / Prezydenci-Kaczynski-i-Juszczenko-signeddeklaracje-o-wspolpracy.html.

Rudnytska U., (2015), The prospects for Baltic Black Sea cooperation in the context of current Russian-Ukrainian relations, Torun International Studies, No. 1. DOI: http://dx.doi.org/10.12775/TIS.2015.009.

Stemplowski R., (2007), Wprowadzenie do analizy polityki zagranicznej RP, Polski Instytut Spraw Międzynarodowych, Warszawa.

Sykulski L., (2009), Geopolityka akademicka między nauką a paradygmatem. Spór wokół semiotyki geopolitycznej, [w:] Między historią a geopolityką, R. Domke (red.), Instytut Geopolityki, Częstochowa.

Sykulski L., (2014), Geopolityka, skrypt dla początkujących, Wydawnictwo Naukowe Grategia, Częstochowa.

Sykulski L., (2018), Geopolityka a bezpieczeństwo Polski, Zona Zero, Warszawa.

Szpak K., (2012), Założenia programowe polityki zagranicznej koalicji rządowej PO-PSL w latach 2007-2011, [w:] Główne kierunki polityki zagranicznej rządu Donalda Tuska w latach 2007-2011, P. Musiałek (red.), Klub Jagielloński, Wydawnictwo eSPe, Kraków.

The days of Russian rule are gone forever. 11th anniversary of Lech Kaczynski's speech in Tbilisi. (2019). URL: https://www.tvp.info/ 43899511 / czasy-dominacji-rosji-sieskonczyly-na-zawsze-11-rocznicaprzemowienia-lecha-kaczynskiego-w-tbilisi. 

Visit of the President of the Republic of Poland to Georgia, (2018), URL: https://www.prezydent.pl/archiwum-lecha- kaczynskiego/aktualnosci/rok- 2007/art,149,901, wizyta-prezydenta-rp-w- gruzji.html
https://dzieje.pl/aktualnosci/prof-m-wolos- koncepcja-federacyjna-jozefa-pilsudskiego- nigdy-nie-umarla-do-konca.
Wyszczeleki L., (2016), Rozumowanie Rosji. Prometeizm - idea i realizacja, Wydawnictwo Bellona, Warszawa.

Visit of the President of Ukraine, (2017), URL: https://www.prezydent.pl/archiwum-lechakaczynskiego/aktualnosci/rok2007/art,149,83, wizyta-prezydentaukrainy.html.

Visit of the presidential couple to Vilnius, (2017), URL: https://www.prezydent.pl/archiwumlecha-kaczynskiego/aktualnosci/rok2007/art,149,132,wizyta-paryprezydenckiej-w-wilnie.html.

Wołos M., (2019), Koncepcja federacyjna Józefa Piłsudskiego nigdy nie umarła do końca, URL :
Zaporowski Z., (2007), Federalizm Józefa Piłsudskiego 1918-1922, [w:] W. Paruch, K. Trembicka (red.), Świat wokół Rzeczpospolitej: problematyka zagraniczna w polskiej myśli politycznej w pierwszej połowie XX wieku, Wydawnictwo UMCS, Lublin.

Zięba R., (2013), Polityka zagraniczna Polski w strefie euroatlantyckiej, Wydawnictwo UW, Warszawa.

Żurawski vel Grajewski P., (2010), Geopolitykasiła-wola. Rzeczpospolitej zmagania z losem, Wydawnictwo Arcana, Kraków. 